\title{
ß-galactosidase production by Saccharomyces fragilis IZ 275 in cheese whey
}

\author{
Alessandra Bosso ${ }^{1} \oplus$, Adriana Aparecida Bosso Tomal ${ }^{2} \oplus$, Lucas Caldeirão Rodrigues Miranda ${ }^{3} \odot$,

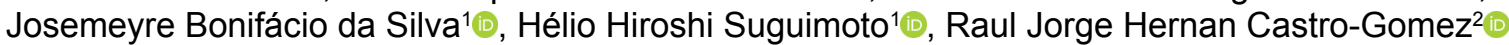

\footnotetext{
1 Universidade Norte do Paraná, Londrina-PR, Brazil. E-mail: alessandrabosso@yahoo.com.br; josibonifacio0576@gmail.com; helio.suguimoto@unopar.br

${ }^{2}$ Universidade Estadual de Londrina, Centro de Ciências Agrárias, Departamento de Ciência e Tecnologia de Alimentos, Londrina-PR, Brazil. E-mail: adriana_bosso@yahoo.com.br; rcastrog@yahoo.com

${ }_{3}^{3}$ Universidade Estadual de Campinas, Faculdade de Engenharia de Alimentos, Departamento de Ciências de Alimentos, Campinas-SP, Brazil. E-mail: Icrmiranda@gmail.com
}

\begin{abstract}
Cheese whey is a byproduct of dairy industry rich in lactose, minerals and proteins which can be used as fermentation medium for microorganism. The parameters of fermentation ( $\mathrm{pH}$, temperature and inoculum) have not so far been optimized. Thus, the objective of this study was to investigate the temperature, $\mathrm{pH}$ and inoculum concentrations parameters using a Central Composite Rotational Design (CCRD) $2^{3}$ and Response Surface Methodology (RSM) to $\beta$-galactosidase production in cheese whey by Saccharomyces fragilis IZ275. The $\beta$-galactosidase production by S. fragilis IZ 275 was evaluated through the enzymatic activity $\left(\mathrm{U} \mathrm{mL} \mathrm{m}^{-1}\right)$ using o-nitrophenyl- $\beta$-D-galactopyranoside substrate (ONPG). All the studied variables were significant and therefore the quadratic model was adequate to explain the effects of the three variables $\left(X_{1}, X_{2}\right.$ and $\left.X_{3}\right)$ on the response function $\left(Y_{1}=\beta\right.$-galactosidase activity). The incubation at $35^{\circ} \mathrm{C}$ of temperature, $\mathrm{pH} 6.0$ and $20 \%$ inoculum concentration guarantees the maximum production $\beta$-galactosidase by Saccharomyces fragilis IZ 275 in supplemented cheese whey.
\end{abstract}

Key words: inoculum; lactase; response surface methodology; temperature; waste

\section{Produção de ß-galactosidase por Saccharomyces fragilis IZ 275 em soro de queijo}

RESUMO: O soro de queijo é um subproduto da indústria de laticínios rico em lactose, minerais e proteínas que pode ser usado como meio de fermentação para microrganismos. Os parâmetros de fermentação (pH, temperatura e concentração de inóculo) ainda não foram otimizados. Assim, o objetivo deste estudo foi investigar os parâmetros de temperatura, pH e concentração de inóculo utilizando um Delineamento Composto Central Rotacional (DCCR) $2^{3}$ e Metodologia de Superfície de Resposta (MSR) para produção de $\beta$-galactosidase em soro de queijo por Saccharomyces fragilis IZ 275. A produção de $\beta$-galactosidase por $S$. fragilis IZ 275 foi avaliada através da atividade enzimática $\left(\mathrm{U} \mathrm{mL}^{-1}\right)$ utilizando o substrato o-nitrofenil- $\beta$-D-galactopiranosídeo (ONPG). Todas as variáveis estudadas foram significativas e, portanto, o modelo quadrático foi adequado para explicar os efeitos das três variáveis $\left(X_{1}, X_{2}\right.$ e $\left.X_{3}\right)$ na função resposta $\left(Y_{1}=\right.$ atividade da $\beta$-galactosidase $)$. A utilização de $35{ }^{\circ} \mathrm{C}$ de temperatura, pH 6,0 e concentração de inóculo de 20\% garante a máxima produção de $\beta$-galactosidase por Saccharomyces fragilis IZ 275 em soro de queijo suplementado.

Palavras-chave: inóculo; lactase; metodologia de superfície de resposta; temperatura; resíduo 


\section{Introduction}

Over 60 percent of the human population has a reduced ability to digest lactose due to low levels of $\beta$-galactosidase enzyme activity. The symptoms of this reduced ability, known as lactose intolerance, include bloating, nausea, abdominal cramping, and diarrhea (Perini et al., 2013; Oak \& Jha, 2018).

$\beta$-galactosidase $\quad$ (EC $\quad 3.2 .1 .23 ; \quad \beta$-D-galactoside galactohydrolase) is an enzyme, commonly known as lactase, that catalyzes the hydrolysis of $\beta-1,4-D$-galactosidic bonds breaking lactose, a disaccharide present in milk and dairy products, into monosaccharide's, glucose and galactose (Panesar et al., 2010; Oliveira et al., 2011; Anisha, 2017). Microorganisms, plant cells, and animal cells (Hussain, 2010) can synthesize $\beta$-galactosidase. However, since microorganisms, such as Aspergillus spp. and Kluyveromyces spp. (species that now includes $K$. fragilis and Saccharomyces fragilis) (Panesar et al., 2006; Hussain, 2010) can produce this enzyme at higher levels, its production is most widely used in the food industry (Saqib et al., 2017).

$\beta$-galactosidase from bacterial sources shows an ease of fermentation, high enzyme activity and good stability. Lactic acid bacteria (LAB), such as lactococci, streptococci, and lactobacilli, owing to their GRAS (generally regarded as safe) status, offer the possibility to be used in the food industry (Hussain, 2010; Lima et al., 2017). $\beta$-galactosidases from fungi are extracellular and thermostable, but susceptible to final product inhibition. $\beta$-galactosidase from yeasts are intracellular enzymes, show a high lactose hydrolyzing capacity, and are therefore used for reduced lactose milk production (Rech \& Ayub, 2007).

The activity of $\beta$-galactosidase, or its production, is also strongly influenced by environmental conditions, such as temperature, inoculum concentration and $\mathrm{pH}$, of the enzyme production and hydrolysis processes (Mlichová \& Rosenberg, 2006; Makwana et al., 2017). The yeast $\beta$-galactosidase has optimal activity at near-neutral $\mathrm{pH}(6.5-7.0)$ and optimal temperature ranging from 35 to $45^{\circ} \mathrm{C}$ (Saqib et al., 2017; Hussain, 2010).

Cheese whey is a by-product produced in high quantities by the dairy industry which, when disposed into water streams, causes water pollution. Considering that over 145 million tons of whey is produced worldwide annually, the desire for new methods to utilize whey can be appreciated (Macwan et al., 2016). The waste or by-product is rich in lactose (approximately $70-72 \%$ of the total solids), minerals and proteins (Gupta, 2000; Saqib et al., 2017) and can be used to make products such as ethanol, and $\beta$-galactosidase that has had a growth in its demand in the manufacturing of lactose free products (Silva et al., 2010; Kokkiligadda et al., 2016).

In addition, the parameters of fermentation medium have not been optimized for $\beta$-galactosidase production by yeast to date. Thus, the objective of this study was to investigate the temperature, $\mathrm{pH}$ and inoculum concentration parameters using a Central Composite Rotational Design (CCRD) $2^{3}$ and
Response Surface Methodology (RSM) for $\beta$-galactosidase production by Saccharomyces fragilis IZ 275 in supplement cheese whey.

\section{Material and Methods}

\section{Microorganism and inoculum}

The Saccharomyces fragilis IZ 275 yeast was collected in the Coleção de Culturas Tropical (WDCM 885 number), was maintained in tubes containing PDA medium (Potato Dextrose Agar) and stored at $4^{\circ} \mathrm{C}$. The microorganism was reactivated in YM broth ( $2 \%$ malt extract and $0.5 \%$ yeast extract, $\mathrm{pH} 5.0$ ) and incubated at $30{ }^{\circ} \mathrm{C}$ for $48 \mathrm{~h}$ in an orbital shaker at 180 rpm (Tecnal, model TE-421). The inoculum was standardized by counting cells in a Neubauer chamber $\left(10^{7}\right.$ cells $\left.\mathrm{mL}^{-1}\right)$ and subsequently transferred (v/v) to the fermentation medium (Prasad et al., 2013; Makwana et al., 2017). The activation medium was pre-autoclaved at $121{ }^{\circ} \mathrm{C}$ for $15 \mathrm{~min}$. The yeast $S$. fragilis IZ 275 was grown in fermentation medium containing cheese whey $\left(17.7 \mathrm{~g} \mathrm{~L}^{-1}\right)$, supplemented with sucrose $\left(14 \mathrm{~g} \mathrm{~L}^{-1}\right)$, glucose $\left(10 \mathrm{~g} \mathrm{~L}^{-1}\right)$, lactose $\left(10 \mathrm{~g} \mathrm{~L}^{-1}\right)$, yeast extract $\left(5.14 \mathrm{~g} \mathrm{~L}^{-1}\right)$, peptone $\left(8.85 \mathrm{~g} \mathrm{~L}^{-1}\right), \mathrm{MgSO}_{4}\left(7 \mathrm{~g} \mathrm{~L}^{-1}\right)$ and $\mathrm{K}_{2} \mathrm{HPO}_{4}\left(5 \mathrm{~g} \mathrm{~L}^{-1}\right)$. The fermentation mediums were autoclaved at $121^{\circ} \mathrm{C}$ for $15 \mathrm{~min}$ prior to addition of the inoculum. All chemicals used in this study were of analytical grade.

\section{Culture conditions}

The experiments were conducted in an orbital rotary incubator (Tecnal, model TE-421, Brazil) with temperature controller and agitation (Viana et al., 2017). The pH of the fermentation mediums was potentiometer adjusted (Hanna Instruments - model $\mathrm{HI} 3221$ ) using solutions of $0.1 \mathrm{M} \mathrm{HCl}$ or $0.1 \mathrm{M} \mathrm{KOH}$. The initial concentration of inoculum $(\mathrm{v} / \mathrm{v})$ was added to the culture medium according to Table 1 . The culture mediums were run in $250 \mathrm{~mL}$ Erlenmeyer flasks containing 100 $\mathrm{mL}$ of fermentation medium, incubated on the orbital shaker (Tecnal, TE-420) at $180 \mathrm{rpm}$, at the temperatures described in Table 1 for $72 \mathrm{~h}$.

\section{$\beta$-galactosidase enzyme extraction}

The $\beta$-galactosidase enzyme extraction was conducted by Prasad et al. (2013) with some modifications. Samples of $80 \mathrm{~mL}$ fermentation medium were centrifuged (Eppendorf centrifuge 5804R, Germany) under conditions of $27.200 \times \mathrm{g}$, $4{ }^{\circ} \mathrm{C}$ for $5 \mathrm{~min}$. The supernatant was resuspended in $0.1 \mathrm{M}$ phosphate buffer, $\mathrm{pH} 6.6$, and centrifuged again under the above conditions. The new precipitate was solubilized in 10 $\mathrm{mL}$ of the same buffer, to which $0.2 \mathrm{~mL}$ of chloroform was added. This mixture was incubated at $37{ }^{\circ} \mathrm{C}$, under agitation of $150 \mathrm{rpm}$ for $17 \mathrm{~h}$. The suspension was then centrifuged and the supernatant used to determine the enzymatic activity.

\section{$\beta$-galactosidase activity}

The enzymatic activity of $S$. fragilis IZ 275 in supplemented cheese whey was determined using the o-nitrophenyl- $\beta-D$ galactopyranoside substrate (ONPG) following the methodology 
described in the Food Chemical Codex (National Academy of Sciences, 1996) with some modifications. The ONPG (1.25 mM) substrate dissolved in $0.05 \mathrm{M}$ sodium phosphate buffer $(\mathrm{pH} 7.0)$ was used. The amount of substrate and enzyme used were 2 $\mathrm{mL}$ and $0.5 \mathrm{~mL}$, respectively. At the time zero, $0.5 \mathrm{~mL}$ of enzyme solution was added to the ONPG solution and incubated for $5 \mathrm{~min}$. The assay was stopped by the addition of $0.5 \mathrm{~mL} 1 \mathrm{M}$ sodium carbonate, and the absorbance was determined in spectrophotometer (Biochrom libra S22 Cambridge England) at $420 \mathrm{~nm}$. One enzymatic unit was defined as the quantity of enzyme that would liberate $1 \mathrm{mM}$ of o-nitrophenol from ONPG per minute under the assay conditions. Enzymatic units were calculated using the Equation 1.

$$
\text { Unit } \mathrm{mL}^{-1}=\frac{\mathrm{A} \times \text { dilution factor }}{\varepsilon \times \text { time } \times \text { enzyme solution }}
$$

where: A was the absorbance at $420 \mathrm{~nm}$, dilution factor was the fold dilution of the enzyme solution, enzyme solution was the amount of enzyme $(\mathrm{mL})$ undergoing the reaction, $\varepsilon$ was the extinction coefficient (determined from the o-nitrophenol standard curve) and time was the incubation time (15 min).

\section{Effect of temperature, $\mathrm{pH}$ and inoculum on the $\beta$-galactosidase production}

To evaluate the effect of temperature, $\mathrm{pH}$ and inoculum concentration on the $\beta$-galactosidase production by $S$. fragilis IZ 275 in supplemented cheese whey culture media, a Rotation Central Composite Design (RCCD) with $2^{3}$ factorial, 6 axial points and 3 replicates at the central point was used, with a total of 17 randomised experiments. Table 1 presents the coded and the real levels of the independent variables: $X_{1}$ (temperature, ${ }^{\circ} \mathrm{C}$ ), $\mathrm{X}_{2}(\mathrm{pH})$ and $\mathrm{X}_{3}$ (inoculum concentration, \%) for the RCCD. The $\beta$-galactosidase production by $S$. fragilis $I Z$ 275 was evaluated by its response function $Y_{1}$ ( $\beta$-galactosidase activity, $\left.\mathrm{U} \mathrm{mL}^{-1}\right)$. The model for response was expressed in the of Equation 2, where $Y_{1}=$ response, $x_{1}, x_{2}$ and $x_{3}=$ levels of the coded variables, $\beta=$ estimated coefficients on the response surface and $\varepsilon=$ pure error.

$$
\begin{aligned}
Y_{1} & =\beta_{0}+\beta_{1} x_{1}+\beta_{2} x_{2}+\beta_{3} x_{3}+\beta_{11} x_{1}^{2}+\beta_{22} x_{2}^{2}+ \\
& +\beta_{33} x_{3}^{2}+\beta_{12} x_{1} x_{2}+\beta_{13} x_{1} x_{3}+\beta_{23} x_{2} x_{3}+\varepsilon
\end{aligned}
$$

The response functions $\left(Y_{1}\right)$ were used to perform regression analyses and analyses of variance (ANOVA) for the regression. The equation model was fitted to experimental data to yield the proposed model. Response surface graphs

Table 1. Coded and real levels of independent variables used in the RCCD $2^{3}$ factorial with 6 axial points.

\begin{tabular}{lccccc}
\hline \multirow{2}{*}{ Independent variables } & \multicolumn{5}{c}{ Levels } \\
\cline { 2 - 7 } & $\mathbf{- 1 . 6 8}$ & $\mathbf{- 1 . 0 0}$ & $\mathbf{0}$ & $\mathbf{1 . 0 0}$ & $\mathbf{1 . 6 8}$ \\
\hline $\mathrm{X}_{1}=$ temperature, ${ }^{\circ} \mathrm{C}$ & 26.6 & 30 & 35 & 40 & 43.4 \\
$\mathrm{X}_{2}=\mathrm{pH}$ & 4.31 & 5.0 & 6.0 & 7.0 & 7.69 \\
$\mathrm{X}_{3}=$ concentration of inoculum, $\%$ & 3.18 & 10 & 20 & 30 & 36.82 \\
\hline
\end{tabular}

and desirability parameters were generated for response function $\left(\mathrm{Y}_{1}\right)$. All analysis, desirability and response surfaces were performed with STATISTICA 7.0 software (StatSoft, 2007).

\section{Model validation}

After response surface analysis and graphing of the desirability for $\beta$-galactosidase maximum activity, the proposed model was validated by performing new assays in triplicate. The results $\left(\mathrm{Y}_{\text {exp }}.\right)$ were compared with the estimated response $\left(\mathrm{y}_{1}\right)$ by Student's t-test $(\mathrm{p}<0.05)$.

\section{Results and discussion}

From the exploratory model of the RCCD block (Table 2 ), the ANOVA and the regression analysis, the effects of variables $X_{1}$ (temperature, ${ }^{\circ} \mathrm{C}$ ), $\mathrm{X}_{2}(\mathrm{pH})$ and $\mathrm{X}_{3}$ (concentration of inoculum, $\%)$ were observed. All variables were significant and therefore the quadratic model was adequate to explain the effects of the three variables $\left(X_{1}, X_{2}\right.$ and $\left.X_{3}\right)$ on the response function $\left(Y_{1}=\beta\right.$-galactosidase activity). $A$ regression analysis and an ANOVA of response function $Y_{1}$ indicated that independent variables $X_{1}$ showed significant linear and quadratic effects and the negative sign, independent variables $X_{2}$ and $X_{3}$ showed significant linear effects and positive sign and quadratic effects and negative sign. The interactions among $x_{1} x_{2}, x_{1} x_{3}$ and $x_{2} x_{3}$ were also significant. Considering all the significant variables, we developed a mathematical model (Equation 3).

$$
\begin{aligned}
Y_{1} & =57.52-23.51 x_{1}-32.04 x_{1}^{2}+11.45 x_{2}-27.99 x_{2}^{2}+ \\
& +3.90 x_{3}-28.36 x_{3}^{2}-9.98 x_{1} x_{2}+2.76 x_{1} x_{3}+1.83 x_{2} x_{3}
\end{aligned}
$$

The lack-of-fit of the model was significant (at $95 \%$ ), and $85.01 \%\left(R^{2}\right)$ of the experimental data was properly adjusted to the model (Table 3). An $R^{2}$ of 0.8501 means that 85.01

Table 2. RDCC for the independent variables $X_{1}$ (temperature, oC), $X_{2}(\mathrm{pH})$ and $\mathrm{X}_{3}$ (inoculum concentration, \%) and response function $Y_{1}(\beta$-galactosidase activity, $U / \mathrm{mL})$.

\begin{tabular}{ccccc}
\hline Assays & $\mathbf{X}_{\mathbf{1}}$ & $\mathbf{X}_{\mathbf{2}}$ & $\mathbf{X}_{\mathbf{3}}$ & $\begin{array}{c}\text { Response } \\
\text { function } \mathbf{Y}_{\mathbf{1}}\end{array}$ \\
\hline 1 & $(-1) 30$ & $(-1) 5.0$ & $(-1) 10$ & 29.69 \\
2 & $(-1) 30$ & $(-1) 5.0$ & $(+1) 30$ & 21.01 \\
3 & $(-1) 30$ & $(+1) 7.0$ & $(-1) 10$ & 46.50 \\
4 & $(-1) 30$ & $(+1) 7.0$ & $(+1) 30$ & 44.62 \\
5 & $(+1) 40$ & $(-1) 5.0$ & $(-1) 10$ & 0.13 \\
6 & $(+1) 40$ & $(-1) 5.0$ & $(+1) 30$ & 0.11 \\
7 & $(+1) 40$ & $(+1) 7.0$ & $(-1) 10$ & 0.12 \\
8 & $(+1) 40$ & $(+1) 7.0$ & $(+1) 30$ & 0.63 \\
9 & $(-1.68) 26.6$ & $(0) 6.0$ & $(0) 20$ & 11.68 \\
10 & $(+1.68) 43.4$ & $(0) 6.0$ & $(0) 20$ & 0.10 \\
11 & $(0) 35$ & $(-1.68) 4.31$ & $(0) 20$ & 0.10 \\
12 & $(0) 35$ & $(-1.68) 7.69$ & $(0) 20$ & 22.71 \\
13 & $(0) 35$ & $(0) 6.0$ & $(-1.68) 3.18$ & 0.10 \\
14 & $(0) 35$ & $(0) 6.0$ & $(-1.68) 36.82$ & 21.93 \\
15 & $(0) 35$ & $(0) 6.0$ & $(0) 20$ & 58.51 \\
16 & $(0) 35$ & $(0) 6.0$ & $(0) 20$ & 58.05 \\
17 & $(0) 35$ & $(0) 6.0$ & $(0) 20$ & 58.11 \\
\hline
\end{tabular}


$\%$ of the variability was explained by the model, which is acceptable for the biological system and $14.99 \%$ was a result of chance. The diagnostic residuals vs. predicted value graph for the response did not present evidence that the residual behavior was not normal or suffered from heteroscedasticity. Moreover, ANOVA indicated that the quadratic mean caused by pure error value (MSpe) resulted in a much lower value (0.063) than the MS residual (182.99). Thus, the $F$ value for the model fit of this response could be overestimated because of the underestimation of its MSpe value, resulting in the observed lack of fit (Ballus et al., 2011). Since it did not adversely affect the search for the optimum conditions and there was a good agreement between the predicted and observed values, we decided to use the model (Bruns et al., 2006; Silveira et al., 2016).

In Table 2, the $\beta$-galactosidase activity was higher in the 15,16 and 17 assays (center points), during the following assay conditions: temperature of $35{ }^{\circ} \mathrm{C}, \mathrm{pH}$ of 6.0 and 20 $\%$, inoculum concentration. Therefore, it was observed that at low temperatures, $\mathrm{pH}$ and inoculum concentration the $\beta$-galactosidase production was lower however, the increase in inoculum concentration does not guarantee an increase in $\beta$-galactosidase activity.

By analysing the response surface in Figure $1 \mathrm{~A}$ it was observed that there is a region in which $\beta$-galactosidase activity was higher between $34-36^{\circ} \mathrm{C}$ and $\mathrm{pH}$ 6.0. In Figure $1 \mathrm{~B}$ the $\beta$-galactosidase activity was higher when $\mathrm{pH}$ equals 6.0 and $20 \%$ inoculum concentration was fixed and in Figure $1 \mathrm{C}$ when the temperature ranged from 30 to $38{ }^{\circ} \mathrm{C}$ and at 10 to $30 \%$ inoculum concentration. The response function methodology confirms the results showed in Table 2 where $\beta$-galactosidase activity was higher when the temperature was $35^{\circ} \mathrm{C}, \mathrm{pH} 6.0$ and at $20 \%$ inoculum concentrations, described in the center points of blocks 15, 16 and 17. It is noteworthy that the maximum $Y_{1}$ included assays of the central point. Different cultivation conditions as temperature, $\mathrm{pH}$, agitation

Table 3. ANOVA for $\beta$-galactosidase production by $S$. fragilis IZ 275 in supplemented cheese whey fermentation medium.

\begin{tabular}{crcrrr}
\hline $\begin{array}{c}\text { Sources } \\
\text { of variation }\end{array}$ & \multicolumn{1}{c}{ SS } & DF & \multicolumn{1}{c}{ MS } & F & pvalue $^{*}$ \\
\hline $\mathrm{X}_{1}$ & 1886.145 & 1 & 1886.145 & 30162.23 & $0.000033^{*}$ \\
$\mathrm{X}_{1}{ }^{2}$ & 2886.656 & 1 & 2886.656 & 46161.88 & $0.000022^{*}$ \\
$\mathrm{X}_{2}$ & 448.165 & 1 & 448.165 & 7166.82 & $0.000140^{*}$ \\
$\mathrm{X}_{2}{ }^{2}$ & 2220.769 & 1 & 2220.769 & 35513.36 & $0.000028^{*}$ \\
$\mathrm{X}_{3}$ & 51.992 & 1 & 51.992 & 831.43 & $0.001201^{*}$ \\
$\mathrm{X}_{3}{ }^{2}$ & 2266.776 & 1 & 2266.776 & 36249.09 & $0.000028^{*}$ \\
$\mathrm{X}_{1} \times \mathrm{X}_{2}$ & 199.101 & 1 & 199.101 & 3183.92 & $0.000314^{*}$ \\
$\mathrm{X}_{1} \times \mathrm{X}_{3}$ & 15.263 & 1 & 15.263 & 244.07 & $0.004072^{*}$ \\
$\mathrm{X}_{2} \times \mathrm{X}_{3}$ & 6.716 & 1 & 6.716 & 107.40 & $0.009183^{*}$ \\
\hline Lack of fit & 1280.770 & 5 & 256.154 & 4096.28 & $0.000244^{*}$ \\
\hline Pure Error & 0.125 & 2 & 0.063 & & \\
\hline Total & 8547.266 & 16 & & & \\
$\mathrm{R}^{2}=0.85$ & & & & & \\
\hline $\mathrm{X}_{1}=0.86$ &
\end{tabular}

$\mathrm{X}_{1}$ (temperature, $\left.{ }^{\circ} \mathrm{C}\right), \mathrm{X}_{2}(\mathrm{pH})$ and $\mathrm{X}_{3}$ (concentration of inoculum, \%); $\mathrm{R}^{2}=$ determination coefficient. *significant $(p<0.05)$.

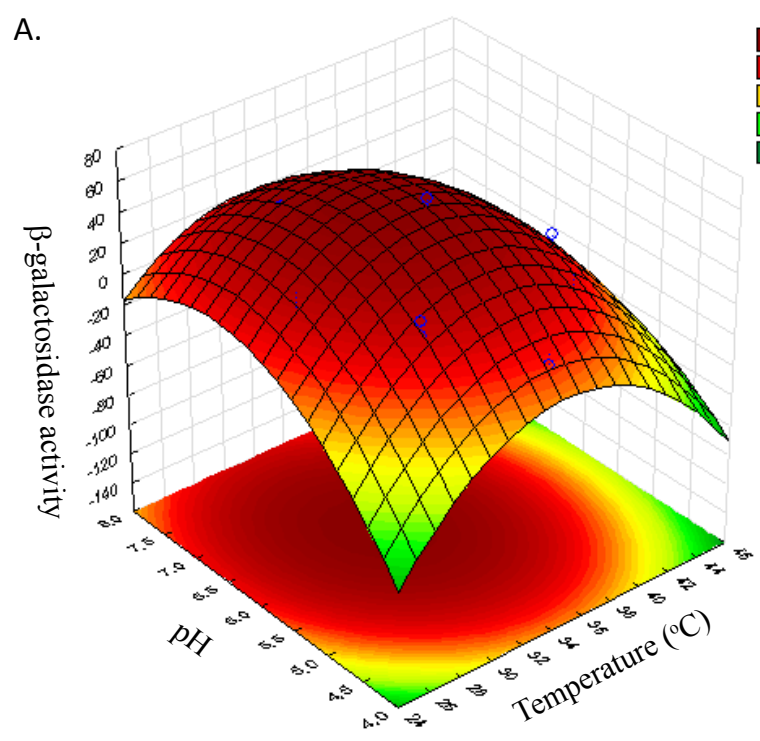

B.
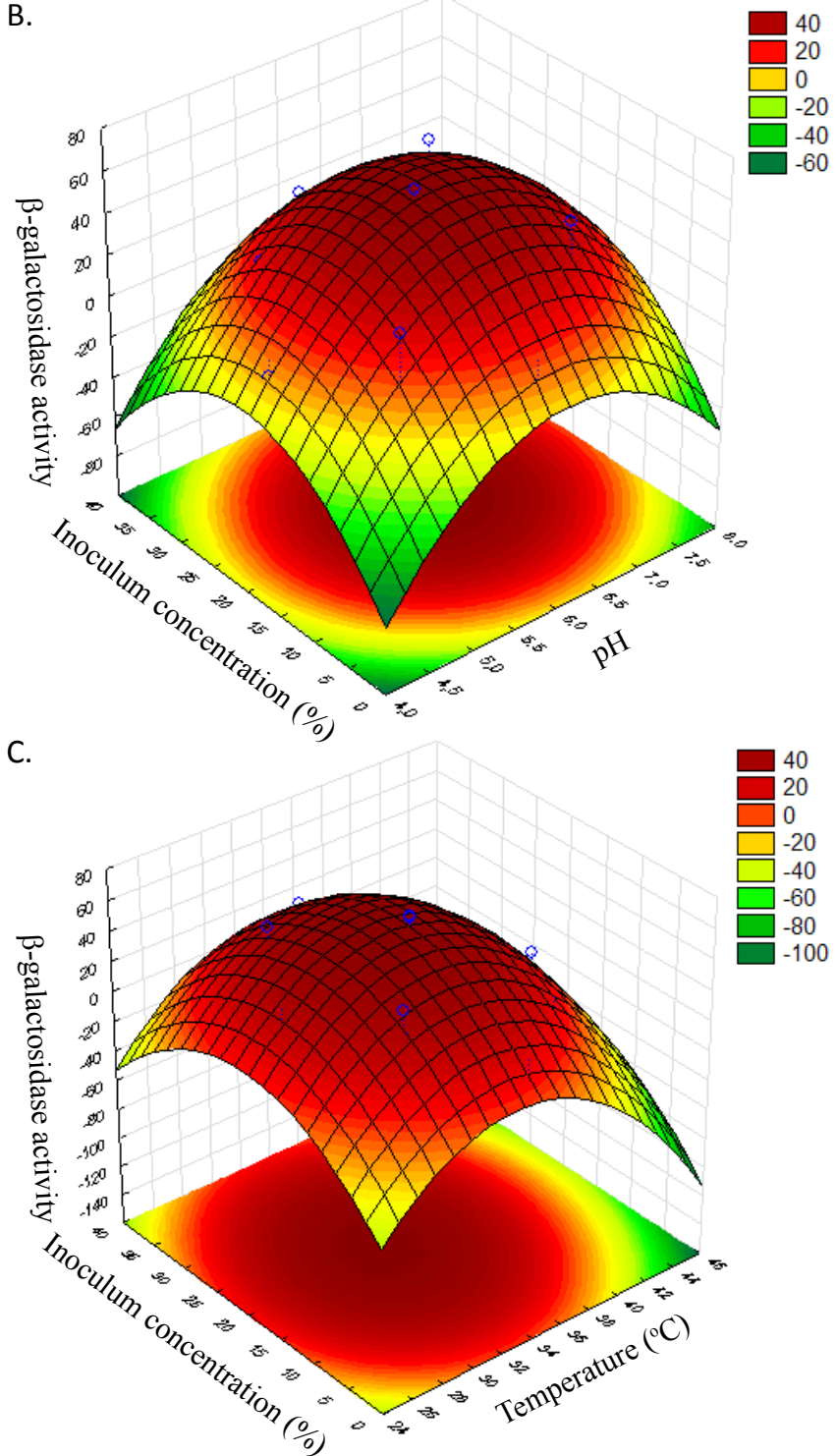

Figure 1. Response surface: (A) $U \mathrm{~mL}^{-1}$ of $\beta$-galactosidase activity as function of temperature $\left({ }^{\circ} \mathrm{C}\right)$ and $\mathrm{pH}$; (B) $\mathrm{U} \mathrm{mL}^{-1}$ of $\beta$-galactosidase activity as function of $\mathrm{pH}$ and inoculum concentration (\%) and (C) $U \mathrm{~mL}^{-1}$ of $\beta$-galactosidase activity as function of temperature $\left({ }^{\circ} \mathrm{C}\right.$ ) and inoculum concentration $(\%)$. 
and incubation time and growth composition can influence the $\beta$-galactosidase production by yeast.

The assays where the best production was achieved, i.e., the optimal enzymatic activity points were determined and repeated experimentally to validate the proposed mathematical model. Calculated and experimental results, showed no significant differences, which validates the proposed mathematical model.

Aspergillus and Kluyveromyces are the most commonly used sources of $\beta$-galactosidase in the food industry since their productivities are higher and products obtained from these organisms possess generally recognized as safe (GRAS) status for human consumption (Makwana et al., 2017; Lima et al., 2017). The extracellular Aspergillus spp. $\beta$-galactosidases have a $\mathrm{pH}$ optimum in the acidic range $(2.5-5.4)$ and a high temperature optimum that allows their use at temperatures up to $50^{\circ} \mathrm{C}$. The Kluyveromyces $\beta$-galactosidases are intracellular, lactose needs to be first transported to the interior of the yeast cell by a permease and then hydrolyzed intracellularly to glucose and galactose. The yeast enzyme has a near-neutral optimum pH (6.0 - 7.0) (Panesar, 2008; Kosseva et al., 2009; Anisha, 2017; Saqib et al., 2017). Perini et al. (2013) showed that the optimum temperature for $\beta$-galactosidase production by Kluyveromyces marxianus (formerly known as Kluyveromyces fragilis and Saccharomyces fragilis) CBS 6556 is found to be 31 ${ }^{\circ} \mathrm{C}$ when associated with $820 \mathrm{~mL} \mathrm{~L}^{-1}$ of cheese whey and 14.36 $\mathrm{g} \mathrm{L}^{-1}$ of corn steep liquor, after $24 \mathrm{~h}$ of culture. In lower corn step liquor concentration $\left(3.64 \mathrm{~g} \mathrm{~L}^{-1}\right)$, the enzyme activity was $20.7 \%$ lower, indicating that a nitrogen source is important to promote enzyme production. Using Kluyveromyces marxianus DIYS11 for $\beta$-galactosidase production, Al-Jazairi et al. (2015) stabilised the optimum levels of initial sugar concentration $(10 \%)$, agitation speed $(250 \mathrm{rpm}), \mathrm{pH}(3)$, incubation time (64 hrs) and temperature $\left(20^{\circ} \mathrm{C}\right)$ to get the maximum specific enzyme activity. Meera et al. (2013) worked with yeast strains and showed that the optimum $\mathrm{pH}$ and temperature for the $\beta$-galactosidase production is $\mathrm{pH}-5\left(96.8 \mathrm{U} \mathrm{mL}^{-1}\right)$ and $35^{\circ} \mathrm{C}$ $\left(53 \mathrm{U} \mathrm{mL^{-1 }}\right)$, respectively, the temperature equals the findings in the present study for higher $\beta$-galactosidase production by Saccharomyces fragilis IZ 275 . There is no work described in the literature that has established optimal conditions for $\beta$-galactosidase production by Saccharomyces fragilis IZ 275 yeast in supplemented cheese whey. The difference showed among the authors confirms that culture medium including $\mathrm{pH}$, temperature, presence of sugar and metal contribute to lower or higher $\beta$-galactosidase production by yeast. The cheese industry produces large quantities of whey as a byproduct, which when disposed into water streams, causes water pollution. Cheese whey is nutritionally rich in lactose, minerals and proteins (Silva et al., 2010; Kokkiligadda et al., 2016; Prashar et al., 2016; Saqib et al., 2017). In this study, cheese whey was used for the growth of Saccharomyces fragilis IZ 275 yeast and it was confirmed that this byproduct could be used as a good fermentation medium in the conditions of $35^{\circ} \mathrm{C}, \mathrm{pH} 6.0$ and $20 \%$ inoculum concentration to obtain maximum production of $\beta$-galactosidase. Lima et al. (2017) optimized the fermentation of goat cheese whey using
Central Composite Rotatable Design (CCRD) and the variable temperature and quantity of prebiotic ingredient to maximize the antilisterial activity and concluded that this by-product is a good fermentation medium.

\section{Conclusion}

The employed response surface methodology proved to be efficient tools to optimize the production of $\beta$-galactosidase by Saccharomyces fragilis IZ 275 in supplemented cheese whey.

The use of $35{ }^{\circ} \mathrm{C}$ of temperature, pH 6.0 and $20 \%$ inoculum concentration assures the maximum production $\beta$-galactosidase by Saccharomyces fragilis IZ 275 in supplemented cheese whey.

\section{Literature Cited}

Al-Jazairi, M.; Abou-Ghorra, S.; Bakri, Y.; Mustafa, M. Optimization of $\beta$-galactosidase production by response surface methodology using locally isolated Kluyveromyces marxianus. International Food Research Journal, v. 22, n. 4, p-1361-1367, 2015. http:// www.ifrj.upm.edu.my/22\%20(04)\%202015/(7).pdf. 25 Aug. 2019.

Anisha, G.S. $\beta$-galactosidases. In: Pandey, A.; Negi, S.; Soccol, C.R. Current developments in biotechnology and bioengineering: production, isolation and purification of industrial products. London: Elsevier, 2017. Chap 17, p.395-421. https://doi. org/10.1016/B978-0-444-63662-1.00017-8.

Ballus, C.A.; Meinhart, A.D.; Bruns, R.E.; Godoy, H.T. Use of multivariate statistical techniques to optimize the simultaneous separation of 13 phenolic compounds from extra-virgin olive oil by capillary electrophoresis. Talanta, v. 83, n.4, p. 1181-1187, 2011. https://doi.org/10.1016/j.talanta.2010.07.013.

Bruns, R.E.; Scarminio, I.S.; Barros Neto, B. Statistical designchemometrics. Amsterdam: Elsevier, 2006. 422p. (Data Handling in Science and Technology, 25).

Gupta, R. S. 2000. The natural evolutionary relationships among Prokaryotes. Critical Reviews in Microbiology, v. 26, n.2, p.111131, 2000. https://doi.org/10.1080/10408410091154219.

Hussain, Q. Beta galactosidases and their potential applications: a review. Critical Review Biotechnology, v. 30, n.1, p.41-62, 2010. https://doi.org/10.3109/07388550903330497.

Kokkiligadda, A.; Beniwal, A.; Saini, P.; Vij, S. Utilization of cheese whey using synergistic immobilization of $\beta$-galactosidase and Saccharomyces cerevisiae cells in dual matrices. Applied Biochemical and Biotechnology, v. 179, n.8, p. 1469-1484, 2016. https://doi.org/10.1007/s12010-016-2078-8.

Kosseva, M.R.; Panesar, P.S.; Kaur, G.; Kennedy, J.F. Use of immobilised biocatalysts in the processing of cheese whey. International Journal of Biological Macromolecules, v. 45, n. 5, p. 437-447, 2009. https://doi.org/10.1016/j.ijbiomac.2009.09.005.

Lima, E.L.; Fernandes, J.; Cardarelli, H.R. Optimized fermentation of goat cheese whey with Lactococcus lactis for production of antilisterial bacteriocin-like substances. LWT - Food Science and Technology, v. 84, p. 710-716, 2017. https://doi.org/10.1016/j. Iwt.2017.06.040. 
Macwan, S.R.; Bhumika, K.D.; Parmar, S.C.; Aparnathi, K.D. Whey and its Utilization. International Journal of Current Microbiology and Applied Sciences, v. 5, n.8, p. 134-155, 2016. https://doi. org/10.20546/ijcmas.2016.508.016.

Makwana, S.; Hati, S.; Parmar, H.; Aparnathi, K.D. Process optimization for the production of $\beta$-galactosidase using potential Lactobacillus cultures. International Journal of Current Microbiology and Applied Sciences, v. 6, n. 8, p. 1454-1469, 2017. https://doi.org/10.20546/ijcmas.2017.608.176.

Meera, N.S.; Theja, P.C.; Devi, M.C. Production and optimization of $\beta$-galactosidase enzyme using probiotic Yeast Spp. Annals of Biological Research, v. 4, n.12, p. 62-67, 2013. https:// www.scholarsresearchlibrary.com/abstract/production-andoptimization-of-bgalactosidase-enzyme-usingrnprobiotic-yeastspp-11458.html. 02 Aug. 2019.

Mlichová, Z.; Rosenberg, M. Current trends of b-galactosidase application in food technology. Journal of Food and Nutrition Research, v. 45, n.2, p. 47-54, 2006. http://www.vup.sk/en/ download.php\%3FbulID\%3D8. 02 Sep. 2019.

National Academy of Sciences. Food chemicals codex. 4.ed. Washington: National Academy Press, 1996. p.802-803.

Oak, S.J.; Jha, R. The effects of probiotics in lactose intolerance: A systematic review. Critical Reviews in Food Science and Nutrition, v. 59, n.11, p. 1-9, 2018. https://doi.org/10.1080/10408398.201 8.1425977.

Oliveira, C.; Guimarães, P.M.R.; Domingues, L. Recombinant microbial systems for improved $\beta$-galactosidase production and biotechnological applications. Biotechnology Advances, v. 29, n.6, p. 600-609, 2011. https://doi.org/10.1016/j. biotechadv.2011.03.008.

Panesar, P.S. Application of response surface methodology for maximal lactose hydrolysis in whole milk using permeabilized yeast cells. Acta Alimentaria, v. 37, n.2, p. 191-203, 2008. https:// doi.org/10.1556/AAlim.2007.0030.

Panesar, P.S.; Kumari, S.; Panesar, R. Potential applications of immobilized $\beta$-galactosidase in food processing industries. Enzyme Research, v.2101, article 473137, p. 1-16, 2010. https:// doi.org/10.4061/2010/473137.

Panesar, P.S.; Panesar, R.; Singh, R.S.; Kennedy, J.F.; Kumar, H. Microbial production, immobilization and applications of $\beta-D$ galactosidase. Journal of Chemistry Technical Biotechnology, $v$. 81, n.4, p. 530-43, 2006. https://doi.org/10.1002/jctb.1453.
Perini, B.L.B.; Souza, H.C.M.; Kelbert, M.; Apati, G.P., Pezzin; A.P.T.; Schneider, A.L.S. Production of $\beta$-galactosidase from cheese whey using Kluyveromyces marxianus CBS 6556. Chemical Engineering Transactions, v. 32, p. 991- 996, 2013. https://www. aidic.it/cet/13/32/166.pdf. 25 Aug. 2019.

Prasad, L.N.; Ghosh, B.C.; Sherkat, F.; Shah, N.P. Extraction and characterisation of $\beta$-galactosidase produced by Bifidobacterium animalis spp. lactis $\mathrm{Bb} 12$ and Lactobacillus delbrueckii spp. bulgaricus ATCC 11842 grown in whey. International Food Research Journal, v. 20, n.1, p. 487-494, 2013. http://www. ifrj.upm.edu.my/20\%20(01)\%202013/66\%20IFRJ\%2020\%20 (01)\%202013\%20Shah\%20(119).pdf. 03 Aug. 2019.

Prashar, A.; Jin, Y.; Mason, B.; Chae, M.; Bressler, D. C. Incorporation of whey permeate, a dairy effluent, in ethanol fermentation to provide a zero waste solution for the dairy industry. Journal of Dairy Science, v. 99, n.3, p-1859-1867, 2016. https://doi. org/10.3168/jds.2015-10059.

Rech, R.; Ayub, M.A.Z. Simplified feeding strategies for fed-batch cultivation of Kluyveromyces marxianus in cheese whey. Process Biochemistry, v. 42, p. 873-877, 2007. https://doi.org/10.14710/ ijred.2.3.127-131.

Saqib, S.; Akram, A.; Halim, A.S.; Tassaduq, R. Sources of b-galactosidase and its applications in food industry. 3Biotech, v. 7, article 79, 2017. https://doi.org/10.1007/s13205-017-0645-5.

Silva, A.C.; Guimarães, P.M.R.; Teixeira, J.Á.; Domingues, L. Fermentation of desproteinized cheese whey powder solutions to ethanol by engineered Saccharomyces cerevisiae: effect of supplementation with corn steep liquor and repeated-batch operation with biomass recycling by flocculation. Journal of Industrial Microbiology \& Biotechnology, v. 37, n.9, p. 973-982, 2010. https://doi.org/10.1007/s10295-010-0748-z.

Silveira, T.F.; Meinhart, A.D.; Souza, T.C.; Teixeira Filho, J.; Godoy, H.T. Phenolic compounds from yerba mate based beverages - a multivariate optimization. Food Chemistry, v. 190, p. 1159-1167, 2016. https://doi.org/10.1016/j.foodchem.2015.06.031.

Statsoft. Statistic (data analysis software system), version 7.0. Tulsa: Statsoft Inc, 2007.

Viana, C.S.; Pedrinho, D.R.; Morioka, L.R.I.; Suguimoto, H.H. Determination of cell permeabilization and beta-galactosidase extraction from Aspergillus oryzae CCT 0977 grown in whey cheese. International Journal of Chemical Engineering, v.2018, Article 1367434, 2018. https://doi.org/10.1155/2018/1367434. 